Jurnal

Kardiologi Indonesia

J Kardiol Indones. 20|4;35:274-7

ISSN 0I 26/3773

Case Report

\title{
Right Anomalous Coronary Artery Origin: The Role of Multislice CT Angiography
}

\author{
Isyana M Kurniawan ${ }^{1,2}$, Elen ${ }^{1}$, Celly A Atmadikoesoemah', Manoefris $\mathrm{K}^{1}$
}

'Department of Cardiology and Vascular Medicine, Faculty of Medicine, Universitas Indonesia National Cardiovascular Center Harapan Kita Hospital-Jakarta ${ }^{2}$ Resident of Department of Cardiology and Vascular Medicine, Faculty of Medicine Universitas Sebelas Maret
Introduction: The anomalous origin of the right coronary artery (RCA) from the left coronary sinus coursing between the aorta and the pulmonary trunk is rare, but may cause myocardial ischemia and sudden death. Multislice CT coronaryangiography offers the possibility to visualize anomalous coronary artery origin non-invasively in details.

Case Illustration: A 54-year-old man with a history of arterial hypertension, and hypercholesterolemia began to present with typical chest pain. After some non-invasive examination, he had coronary angiographythat revealed $70 \%$ stenosis at mid intermediate artery, normalLMCA, LAD and LCX. Ostium of RCA was found near the left valsava sinus afterrepeated cannulation attempts, no stenosis was found at RCA. After successful revascularization at intermediate artery, patient still had typical chest pain with positive ischemic response in treadmill test. Multislice CT coronary angiography was performedto evaluate the etiology of chest pain. The scan showed patent stent at intermediate artery and anomalous RCA origin from the left coronary sinus withacute angle take-off, luminal narrowing of the osteal-proximal part, as well as luminal compression between the ascending aorta and the pulmonary trunk (an interarterial course) while RCA appeared as dominant vessel. These features were considered as malignant coronary anomaly that could lead to the recommendation of surgical correction.

Discussion: Accurate recognition and documentation of coronary artery anomalies are essential to determine the significance of such findings and to avoid furtherclinical complications. Multislice CT coronary angiography is a non-invasive imaging modality that can easily and precisely depict the origin and course of coronary artery anomalies as well as its relationship with adjacent structures.

(J Kardiol Indones. 20 14;35:274-7)

Keywords: right anomalous coronary artery origin, multislice CT coronary angiography 
Jurnal

Laporan Kasus

Kardiologi Indonesia

J Kardiol Indones. 2014;35:274-7

ISSN 0I 26/3773

\title{
Anomali Pangkal Arteri Koroner: Peran CT Angiografi
}

\author{
Isyana M Kurniawan ${ }^{1,2}$, Elen' ${ }^{1}$ Celly A Atmadikoesoemah', Manoefris K'
}

\begin{abstract}
Pendahuluan Kasus anomali dimana arteri koroner kanan berasal dari sinus koronarius kiri yang melintas diantara aorta dan arteri pulmonalis adalah jarang, namun dapat menyebabkan iskemia miokardium dan kematian jantung mendadak. Pencitraan dengan multislice CT angiografi koroner dapat mendeteksi anomali arteri koroner secara detail dan non invasif.

Ilustrasi Kasus Laki laki berusia 54 tahun dengan riwayat hipertensi dan hiperkolesterolemia datang dengan keluhan nyeri dada tipikal. Setelah dilakukan beberapa pemeriksaan non invasif, pasien menjalani angiografi koroner dan didapatkan stenosis $70 \%$ pada arteri mid intermediate, normal arteri koroner cabang utama, arteri koroner anterior desendens, dan arteri koroner sirkumfleksa. Ostium arteri koroner kanan ditemukan setelah beberapa usaha kanulasi dan terletak dekat sinus valsava kiri. Tidak didapatkan stenosis pada arteri koroner kanan. Setelah dilakukan revaskularisasi pada arteri intermediate dengan sukses, pasen masih mengeluh nyeri dada tipikal dengan respon iskemik positif pada uji latih jantung. MSCT angiografi koroner dilakukan untuk evaluasi etiologi nyeri dada. Hasil MSCT angiografi koroner menunjukkan bahwa stent pada arteri intermediate paten dan anomali arteri koroner kanan dimana berasal dari sinus koronarius kiri dengan sudut yang berbelok tajam, penyempitan lumen pada bagian osteal-proksimal, serta adanya kompresi lumen antara aorta asendens dengan arteri pulmonalis (interarterial course) dimana arteri koroner kanan merupakan pembuluh darah dominan. Anomali ini dianggap sebagai anomali koroner yang malignan dan memerlukan rekomendasi koreksi pembedahan.

Diskusi Deteksi akurat dan dokumentasi anomali arteri koroner penting untuk menentukan apakah anomali tersebut menngakibatkan dampak yang signifikan atau tidak dan untuk menghindari komplikasi klinis lebih lanjut. MSCT angiografi koroner adalah modalitas pencitraan non invasif yang dapat dengan mudah dan teliti untuk mendapatkan asal maupun jalur anomali arteri koroner dan hubungannya dengan anatomi struktur lainnya.
\end{abstract}

(J Kardiol Indones. 2014;35:274-7)

Kata Kunci : right anomalous coronary artery origin, MSCT angiografi koroner

\begin{abstract}
Alamat Korespondensi
Dr. Isyana M Kurniawan, I Department of Cardiology and Vascular Medicine, Faculty of Medicine, Universitas Indonesia - National Cardiovascular Center Harapan Kita Hospital-Jakarta. ${ }^{2}$ Resident of Department of Cardiology and Vascular Medicine, Faculty of Medicine Universitas Sebelas Maret. Tel. 081392215220, E-mail: kristianikurniawan@gmail.com
\end{abstract}

\section{Introduction}

The anomalous origin of the right coronary artery (RCA) from the left coronary sinus (LCS) coursing between the aorta and the pulmonary trunk is rare, but may cause myocardial ischemia and sudden death. ${ }^{1}$ Multislice CT coronary angiography offers 
the possibility to visualize anomalous coronary artery origin non-invasively in details. ${ }^{2}$

\section{Case Report}

A 54-year-old man with a history of arterial hypertension, and hypercholesterolemia began to present with typical chest pain. After some noninvasive examination, he had coronary angiography that revealed $70 \%$ stenosis at mid intermediate artery, normal LMCA, LAD and LCX. Ostium of RCA was found near the left valsava sinus after repeated cannulation attempts, no stenosis was found at RCA.
After successful revascularization at intermediate artery, patient still had typical chest pain with positive ischemic response in treadmill test.

Multislice CT coronary angiography was performed to evaluate the etiology of chest pain. The scan showed patent stent at intermediate artery and anomalous RCA origin from the left coronary sinus with acute angle takeoff, luminal narrowing of the osteal-proximal part, as well as luminal compression between the ascending aorta and the pulmonary trunk (an interarterial course) while RCA appeared as dominant vessel. Measurement of diameters for proximal and mid segments of the RCA were $2,1 \mathrm{~mm}$ and 3,9 $\mathrm{mm}$, respectively. (Figure 1)
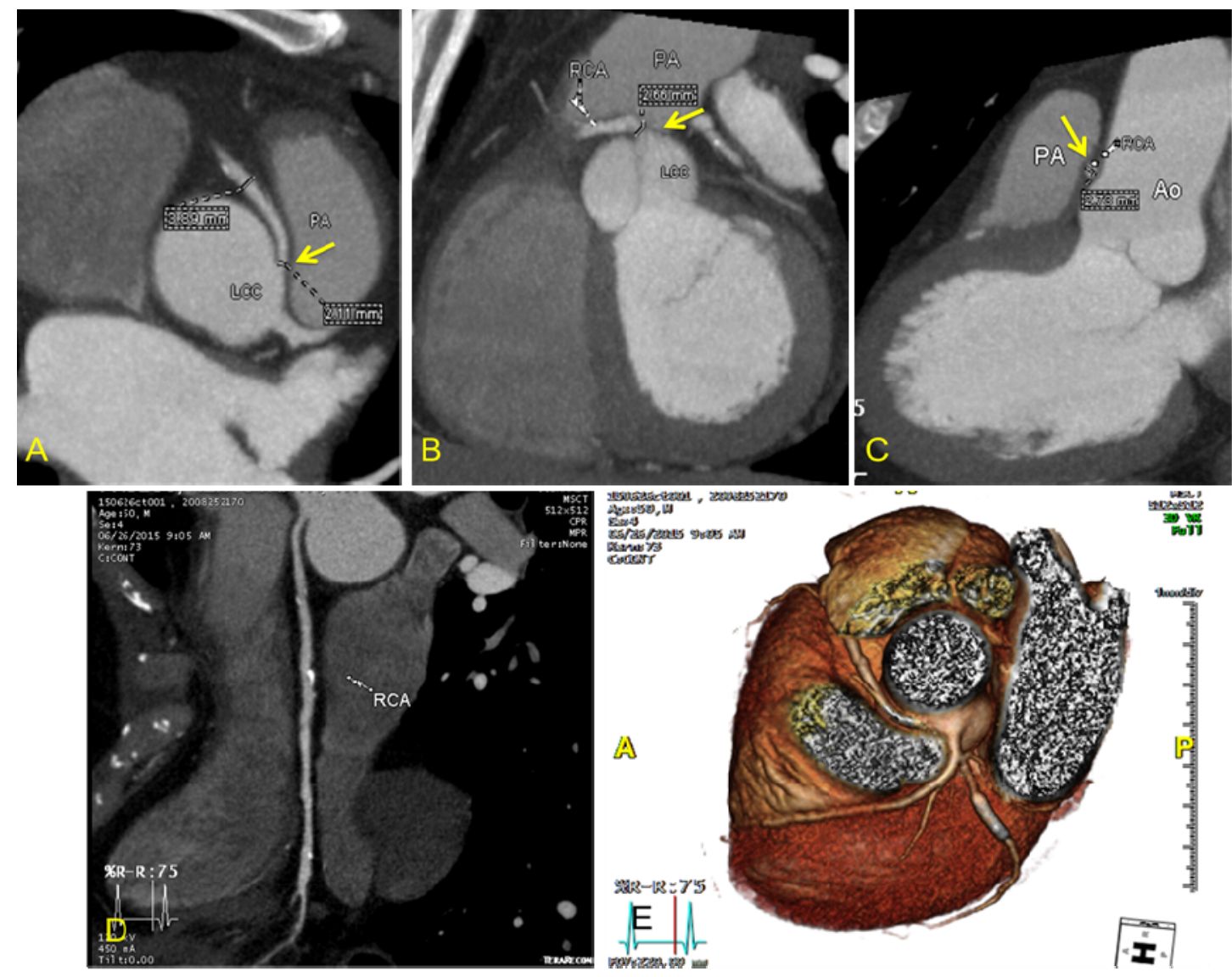

Figure 1. Oblique axial MPR imaging (A) shows luminal narrowing (arrow) of the proximal portion of the anomalous RCA, as well as a small orifice with acute angle takeoff, the oblique sagittal MPR (B) image shows an anomalous RCA (arrow) arising from left coronary sinus. Oblique coronal MPR imaging (C) shows an interarterial course with luminal compression (arrow). Axial MPR imaging (D) shows luminal narrowing of the proximal portion of the anomalous RCA. Volume rendered cranial view (E) shows RCA arising from the left coronary sinus (an interarterial course). MPR: multiplanar recostruction, RCA: right coronary artery, PA: pulmonary artery, Ao: aorta, LCC: left coronary sinus, RCC: right coronary sinus 


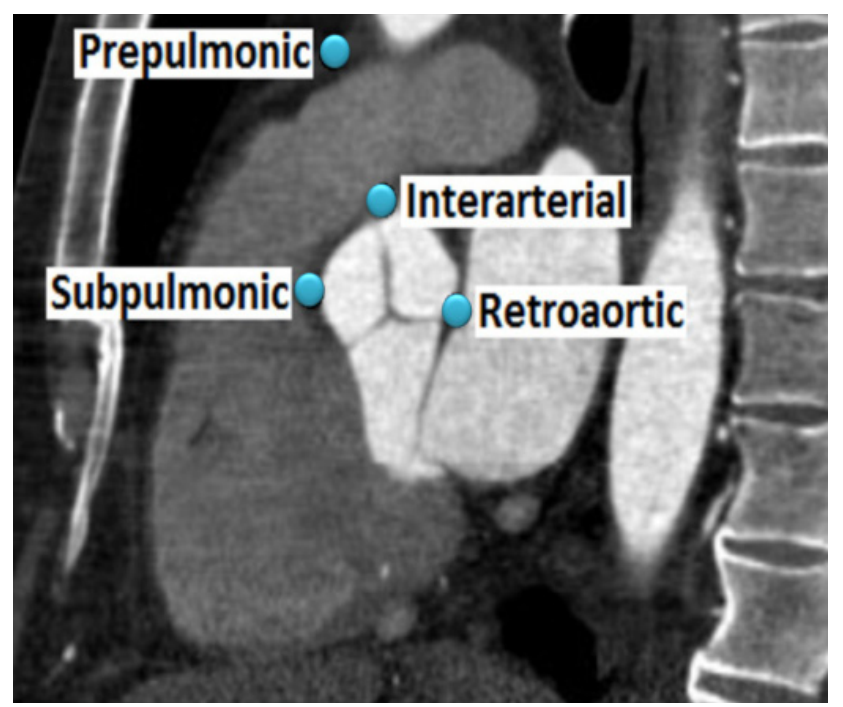

Figure 2. Scheme of anomalous coronary pathway to reach their normal positions.

\section{Discussion}

The incidence of the anomalous origin of the RCA from the LCS is $0.019 \%$ to $0.49 \%$ on coronary angiography. ${ }^{3}$ As Eckart et al report also suggests, evidence from autopsy series indicates that anomalous origin of the RCA from the LCS is associated with sudden cardiac death in $25 \%$ of cases. ${ }^{4} \mathrm{~A}$ coronary artery arising at improper sinus follows one of the four possible pathways to reach theirnormal positions. The aberrant vessel may course posterior to the aorta (retroaorta), or between the ascending aorta and pulmonary artery (interarterial), prepulmonary artery (prepulmonic), or septal (subpulmonic)..$^{5}$ (Figure 2)

An interarterial course is associated with risk of myocardial ischemia ("malignant anomaly") because it generally occurs with: a small, slit-like orifice, acute angle takeoff, potential of compression between the great vessels during exercise, due to expansion of the aortic root and pulmonary artery trunk root, and the artery with the anomalous course can be the dominant artery. ${ }^{6}$ Study of the proximal structures, including the takeoff portion, is important in formulating a treatment plan. MSCT coronary angiography is the favored imaging method. ${ }^{3}$ In our patient, coronary anomaly were considered as malignant that could lead to the recommendation of surgical correction.

\section{Summary}

We have bee $\mathrm{n}$ reported a case of a patient in whom evaluation of angina pectoris revealed an anomalous RCA arising from the LCS with interarterial course (malignant coronary anomaly) by multislice CT coronary angiography.

Accurate recognition and documentation of coronary artery anomalies are essential to determine the significance of such findings and to avoid complications. Conventional coronary angiography is the standard to assess coronary artery disease, but it has some limitations because of limited number of $2 \mathrm{D}$ projection images. Multislice CT coronary angiography is non-invasive imaging modality that can precisely depict the origin and course coronary artery anomalies and is recommended if coronary artery anomaly is suspected, particularly when canulation in coronary angiography was difficult.

\section{References}

1. Sato Y, Inoue F, Naoya M, et al. Detection of anomalous origins of the coronary artery by means of multislice computed tomography. Circ J 2005;69:320-324.

2. Erol C, Koplay M, and Paksoy Y. Evaluation of anatomy, variation and anomalies of the coronary arteries with coronary computed tomography angiography. Anadolu Kardiyol Derg 2013;13:154-64

3. Bae YL. Anomalous right coronary artery from the left coronary sinus with an interarterial course: Is it really dangerous? Korean Circ. J 2009;39, 175-179.

4. Angelini P. Novel imaging of coronary artery anomalies to assess their prevalence, the causes of clinical symptoms, and the risk of sudden cardiac death. Circ. Cardiovasc. Imaging 2014;7:747-754.

5. Qin X, Xiong W, Guan E, et al. Coronary anomaly : anomalous right coronary artery originates from the left sinus of Valsalva and coursing between the pulmonary artery and aorta. Clinical Interventions in Aging 2013; 8: 1217-1220.

6. Demir S, Karakaya Z, Tüfenk M, et al. An anomalous right coronary artery with interarterial course diagnosed by multislice computed tomography. Kosuyolu Kalp Derg 2013;16, 159-161. 